\title{
ARHGEF2 wt Allele
}

National Cancer Institute

\section{Source}

National Cancer Institute. ARHGEF2 wt Allele. NCI Thesaurus. Code C101781.

Human ARHGEF2 wild-type allele is located within 1q21-q22 and is approximately $50 \mathrm{~kb}$ in length. This allele, which encodes Rho guanine nucleotide exchange factor 2 protein, plays a role in signaling, apoptosis, and cell proliferation. 